\title{
Refining stratigraphic ages of Northern Hsuehshan Range in northern Taiwan by detrital zircon $\mathrm{U}-\mathrm{Pb}$ dating
}

\author{
Ling-Ho Chung ${ }^{1,2}$, Yuan-Hsi Lee ${ }^{1, *}$, Wan-Ling Tsai ${ }^{1}$, Kai-Shuan Shea ${ }^{3}$, Louis S. Teng ${ }^{4}$, Wei Lo ${ }^{5}$, and \\ $\mathrm{Xi}-\operatorname{Bin} \operatorname{Tan}^{6}$ \\ ${ }^{1}$ Department of Earth and Environmental Sciences, National Chung Cheng University, Chiayi, Taiwan \\ ${ }^{2}$ National Museum of Natural Sciences, Taichung, Taiwan \\ ${ }^{3}$ Central Geological Survey, MOEA, Taipei City, Taiwan \\ ${ }^{4}$ Department of Geosciences, National Taiwan University, Taipei City, Taiwan \\ ${ }^{5}$ Department of Materials and Mineral Resources Engineering, National Taipei University of Technology, Taipei City, Taiwan \\ ${ }^{6}$ Institute of Geology, China Earthquake Administration, Beijing, China
}

\section{Article history: \\ Received 6 July 2016 \\ Revised 9 October 2017 \\ Accepted 19 October 2017}

Keywords:

Hsuehshan Range, Detrital U-Pb zircon dating, Hsitsun Formation, Szeleng Sandstone

Citation:

Chung, L.-H., Y.-H. Lee, W.-L. Tsai, K.-S. Shea, L. S. Teng, W. Lo, and X.-B. Tan, 2018: Refining stratigraphic ages of Northern Hsuehshan Range in northern Taiwan by detrital zircon U-Pb dating. Terr. Atmos. Ocean. Sci., 29,291-300, doi: 10.3319/ TAO.2017.10.19.01

\begin{abstract}
Taiwan is located on northern margin of South China Sea, which evolved from rifting basin to passive margin from Paleocene to Miocene. The northern Hsuehshan Range exposes the Eocene to Miocene strata, which offers a unique place to study the rifting basin history. However, the strata ages in the northern Hsuehshan Range are controversial, particularly for the Hsitsun Formation and Szeleng Sandstone that may correlate with a proposed break-up unconformity in the Eocene and Oligocene. Previously, the Hsitsun Formation was considered to be pre-Early to Middle Eocene in age based on the presence of Nummulites junbarensis in the overlying Szeleng Sandstone. In this paper, we present new U-Pb ages of detrital zircon grains from the Hsitsun Formation and Szeleng Sandstone to constrain the depositional ages of these units. In the Hsitsun Formation, ca. 8\% of zircon U-Pb grains are Cenozoic in age and have a mean age of $35 \mathrm{Ma}$ indicating that the maximum deposition age of late Eocene for this formation. Combining these results with the ca. $30 \mathrm{Ma}$ age for Paling Formation indicates the Szeleng Sandstone is between 30 - 35 Ma. The new ages determinations suggest that the deposition was continuous with no evidence of a break-up unconformity from Szeleng Sandstone to Paling Formation. Finally, because much of the stratigraphic interpretations and correlations are based on what were interpreted to be "in situ" biostratigraphic markers, the new U-Pb dates argue for recycling and reworking of several key fossil assemblages. This result has important implications for other stratigraphic interpretations both in Taiwan and in other orogenic systems around the world.
\end{abstract}

\section{INTRODUCTION}

The continental margin of Eurasia plate started to become a rifting margin in early Cenozoic and changed to passive margin during the Miocene (Teng 1990; Teng et al. 1991; Lin et al. 2003). Due to the arc continental collision in late Miocene, the Eocene rifting basin strata was exposed to surface in Taiwan orogenic belt, providing a unique area to study the rift basin evolution of the Eurasia continental margin (Huang et al. 2012; Lee et al. 2015) (Fig. 1). The

\footnotetext{
* Corresponding author

E-mail:seilee@eq.ccu.edu.tw
}

northern Hsuehshan Range exposes the Eocene to Miocene strata along the Northern Cross Highway, which provides a good transect to discuss the rifting basin evolution in continental margin (Fig. 1a). Based on the paleontology and sedimentology evidences, Huang et al. (2012) proposed a deposition gap exists between the middle Eocene and Oligocene (39 - 33Ma) in the northern Hsuehshan Range and this gap resulted from continental break-up associated with the formation of South China Sea oceanic Crust (Fig. 2). Other studies, in contrast suggest that no deposition gap from late Paleocene to Miocene exists (Chang 1975; Chen 2016) (Fig. 2). The different stratigraphic ages for the units 


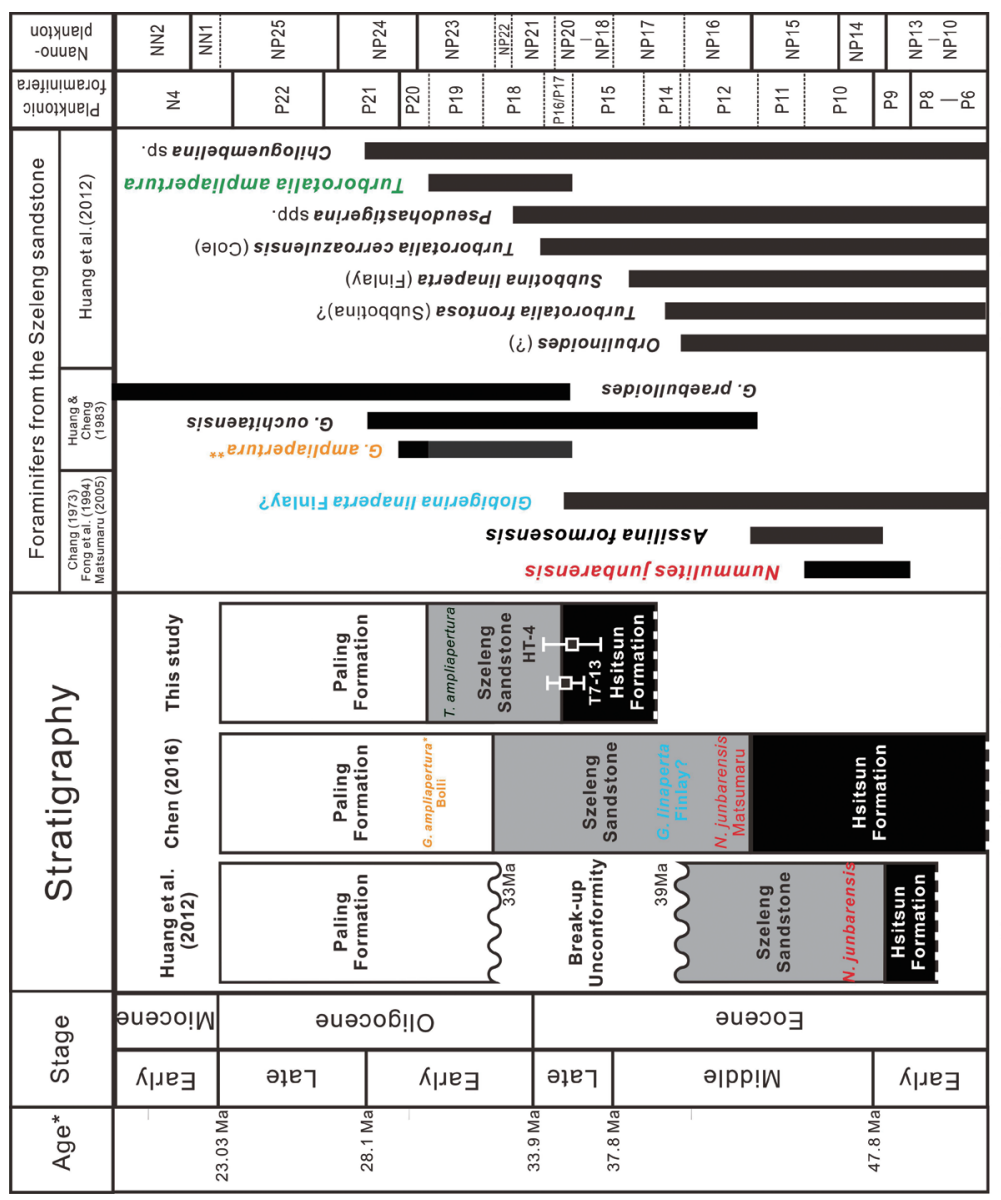
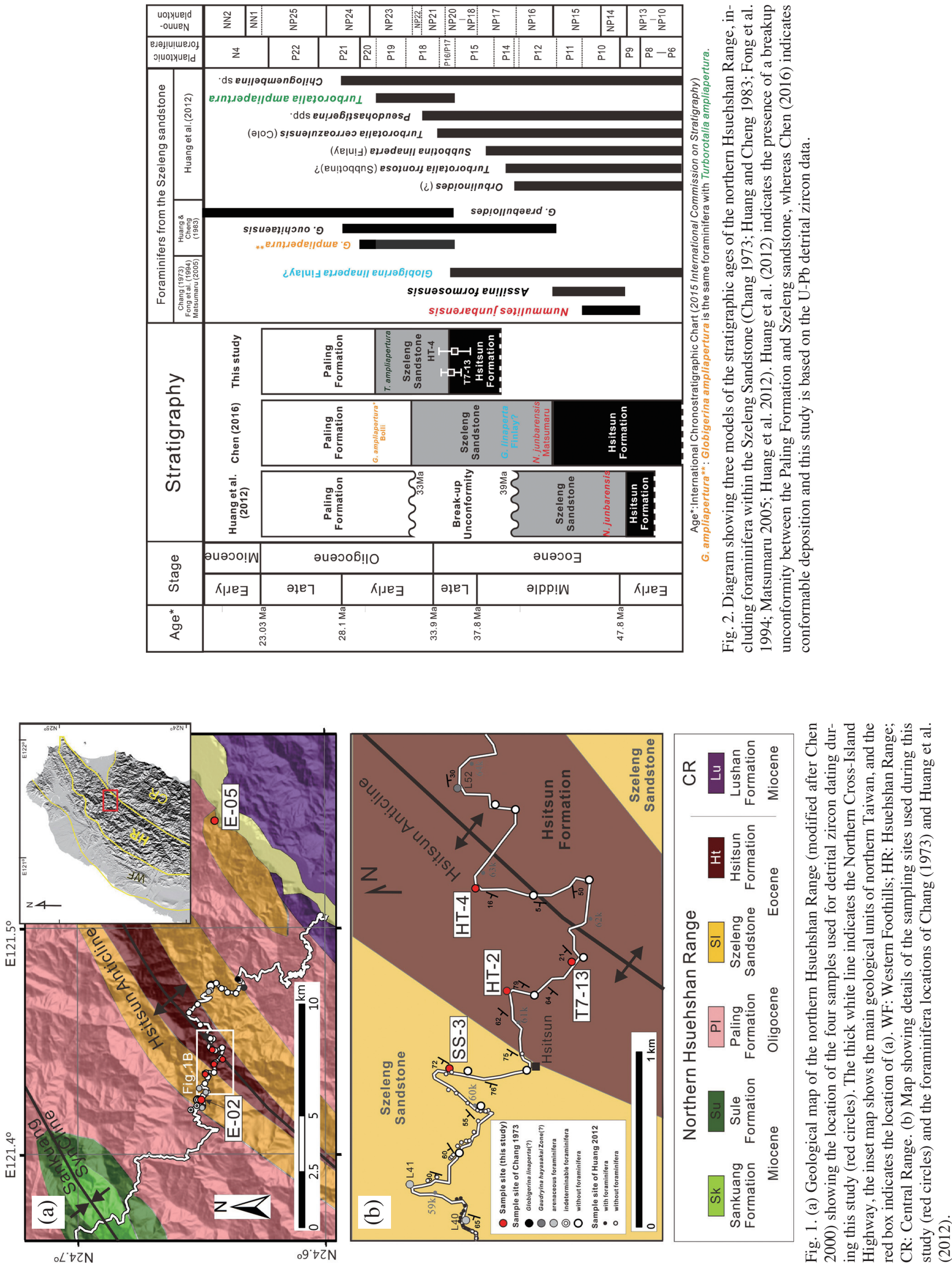
in the northern Hsuehshan Range also results in different stratigraphy correlations between the northern to southern parts of the Hsuehshan Range (Shea 2009; Shea et al. 2011). Well-constrained stratigraphy ages, therefore, are a key to better understanding the stratigraphic correlations in the Hsuehshan range to reconstructing the history of rifting in the South China Sea.

Previously the stratigraphic ages in the northern Hsuehshan Range were constrained using field relationship and paleontology data. In an effort to better constrain the ages and possibly provide answers to the abovementioned questions, we applied the zircon U-Pb dating technique to two previously identified units: the Hsitsun Formation and Szeleng Sandstone. The closure temperature of zircon $\mathrm{U}-\mathrm{Pb}$ dating is ca. $800-900^{\circ}$ indicating that the U-Pb zircon grain age is the age of crystallization of the zircon grains and ages are not easily affected during the diagenetic to metamorphic processes (Harley et al. 2007). Detrital zircon U-Pb ages, therefore, are powerful tools for studying to the provenance problems (Morton et al. 1996; Košler et al. 2002). In addition, the youngest zircon ages can constrain the maximum deposition age (DeCelles et al. 2007; Dickinson and Gehrels 2009; Tucker et al. 2013). In this study, we obtained detrital zircon U-Pb ages and found that ca. $8 \%$ of the obtained data set has Cenozoic zircon grains in the Hsitsun Formation, which is the oldest mapped unit in northern Hsuehshan Range. The results provide a unique chance to refine the stratigraphic ages in this part of the range and they provided critical constraints on correlating units throughout the rest of the Hsuehshan Range.

\section{REGIONAL GEOLOGY AND STRATIGRAPHY}

The Hsuehshan Range is located in northern Taiwan between the Western Foothills to the west and the Central Range to the east, and exposes a thick Oligocene sedimentary sequence with minor amounts of upper Eocene and Miocene sediments (Fig. 1a). These sedimentary sequences were deposited during the rifting (Paleocene to Eocene) to post-breakup stage (Miocene) of the formation of the South China Sea (Teng 1990; Lin et al. 2003). Continuous magmatism events have been observed during the rifting stage (Chung et al. 1995; Lin et al. 2003). Sedimentation occurred primarily in a half-graben recognized as the Hsuehshan Trough (Ho 1986; Teng 1990; Teng et al. 1991; Lin et al. 2003; Yu et al. 2013). The Northern Cross-Island Highway exposes a thick Eocene to Miocene sequence represented by the Hsitsun Formation, the Szeleng Sandstone, the Paling Formation, and two overlying Miocene units, the Sule and Sankuang Formation (Fig. 1).

The Hsitsun Formation crops out in the core of the Hsitsun anticline and was first described by Ooe (1931). Before 1980, most researchers interpreted the Hsitsun Formation and Szeleng Sandstone to be late Eocene age and conformably overlain by Oligocene Paling Formation; however there was no paleontological evidence to support this interpretation (Chang 1975). Later, in the Szeleng Formation a dense layer of Nummulites junbarensis foraminifera was discovered in the Sezleng Sandstone (Fong et al. 1994) and Matsumaru (2005) correlated N. junbarensis with the NP 14 nannofossil zone and the P9 - P10 planktonic foraminifera zones in Japan, suggesting an Early to Middle Eocene biostratigraphic age for the Szeleng Sandstone (ca. 47.3 - 49.7 Ma) (Fig. 2). This indicated that the Hsitsun Formation could be from late Paleocene to early Eocene age (Huang 2007; Huang et al. 2012; Chen 2016). The Paling Formation, which overlies on the Szeleng Sandstone, has a biostratigraphic age of ca. $30 \mathrm{Ma}$, as evidenced by the presence of a Globigerina ampliapertura zone (Zone P20/N1; Chang 1962, 1973). Considering the strata age gap, Huang (2007) suggested the presence of either an unconformity or very low sedimentation rates between the Szeleng Sandstone and the Paling Formation. Huang et al. (2012) identified numerous carbonate planktonic foraminifera within the upper part of the Szeleng Sandstone that suggested a biostratigraphic ages of Middle Eocene or Middle Eocene to Oligocene. The last appearance datum (LAD) of these planktonic foraminifera led Huang et al. (2012) to suggest that the Middle Eocene age was more accurate and proposed that the depositional gap was related to breakup unconformity during the opening of the South China Sea (Fig. 2). A recent study by Chen (2016) suggests that the stratigraphic age of the Szeleng Sandstone may extend from middle Eocene to late Miocene and also that there is no deposition gap between the Szeleng Sandstone and Paling Formation. He also suggested that the stratigraphic age of the Hsitsun Formation may be late Paleocene to middle Eocene (Fig. 2).

\section{METHODS AND SAMPLES}

Six metasandstone samples were collected along the Northern Cross-Island Highway from the Hsitsun Formation and Szeleng Sandstone (Fig. 1). Three of these samples (T7-13, HT2, and HT4) were obtained from the Hsitsun Formation. One sample SS3 was collected from the bottom of Szeleng Sandstone based on the 1:500000 geological map of Taiwan (Chen 2000) and detailed mapping by Huang et al. (2012; Fig. 1b). The two remaining samples (E02 and E05) were collected from the Szeleng Sandstone. The U-Pb ages of at least 50 zircons from each sample were analyzed by laser ablation-inductively coupled plasma-mass spectrometry (LA-ICP-MS) at National Chung-Cheng University, Chiayi, Taiwan, following Chiu et al. (2009) and Knittel et al. (2014). These analyses used an Agilent 7500s quadrupole ICP-MS equipped with a New Wave UP213 LA system. The resulting analyses were calibrated using GJ-1 (Jackson et al. 2004) and Plešovice (Sláma et al. 2008) standard zircons, and all U-Th-Pb isotope ratios were calculated 
using GLITTER 4.4.2 (GEMOC) software. Common lead was corrected following Andersen (2002), and weighted mean U-Pb ages, probability density curves, and concordia were determined using Isoplot v. 3.0 (Ludwig 2003).

\section{RESULTS}

A total of $519 \mathrm{U}-\mathrm{Pb}$ detrital zircon ages were obtained from the six metasandstone samples with ages ranging from $2.5 \mathrm{Ga}$ to ca. $33 \mathrm{Ma}$ (Appendix A). Most of the analyzed zircon grains were 100 - $200 \mu \mathrm{m}$ long, $\sim 100 \mu \mathrm{m}$ wide and are euhedral. Cathodoluminescence (CL) imaging representative grains indicate that the majority contain tight oscillatory zoning that is indicative of an igneous origin (Fig. 3). Histograms of the ages show that about half of the zircons are Mesozoic in age with ages ranging from ca. $170-100 \mathrm{Ma}$; additional minor peaks are at $230-260,400-450 \mathrm{Ma}$ and some Cenozoic ages (Fig. 4). Age spectra and concordia diagrams for these zircons are given in Figs. 4 and 5, respectively, and the age distribution for each sample is discussed below.

(1) E02 is collected from the top of the Szeleng Sandstone. 100 zircon grains were analyzed and ca. $60 \%$ grain ages are between 88 and $200 \mathrm{Ma}$ (Figs. $4 \mathrm{a}$ and b).

(2) E05 is collected from the eastern margin of the Szeleng Sandstone (Fig. 1a). 108 grains were analyzed and ca. 60\% grain age are younger than $200 \mathrm{Ma}$. Two Cenozoic grain ages were observed at 41 and $51 \mathrm{Ma}$ (Figs. $4 \mathrm{c}$ and d).
Sample T7-13 was collected near the core of the Hsitsun anticline (Fig. 1b). A total of 105 zircons from this sample were analyzed, yielding 14 Cenozoic ages (Fig. 4e) and 43 grains have ages between 90 and $170 \mathrm{Ma}(41 \%$ of the zircon population; Fig. 4f). Two mean ages were obtained from the Cenozoic zircons: 7 zircons with ages between 33.9 and $37 \mathrm{Ma}$ yield a mean age of $35.3 \pm 0.7 \mathrm{Ma}$ (MSWD $=1.2$ ), and 6 zircons with ages between 37 and 41 Ma yield a mean age of $39.2 \pm 1.2 \mathrm{Ma}$ (MSWD = 1.4; Fig. 6a). These ages indicate that sample T7-13 was deposited after $\sim 35 \mathrm{Ma}$ (i.e., during the Late Eocene).

Sample HT4 was also collected from a few hundred meters northwest of T7-13 and also near the core of the Hsitsun anticline (Fig. 1b). A total of 89 zircons from this sample were analyzed, yielding 30 zircons with ages younger than $200 \mathrm{Ma}$ (Figs. 4g and h). Seven Cenozoic zircons yielded a mean age of $35.4 \pm 1.1 \mathrm{Ma}$ (MSWD = 1.8; Fig. 6b). Samples HT4 and T7-13 have similar age distributions and similar youngest mean ages (Cenozoic, ca. $35 \mathrm{Ma}$ ) that indicate that the ages of the detrital zircons in these samples accurately reflect the provenance of these sediments, suggesting that these two samples were derived from similarly aged protoliths (Fig. 4).

Almost half of the total of 55 zircons from sample HT2 yielded ${ }^{206} \mathrm{~Pb} /{ }^{238} \mathrm{U}$ ages of $461-91 \mathrm{Ma}$ with a major peak around $450 \mathrm{Ma}(\mathrm{n}=31$; Figs. $4 \mathrm{i}$ and j). The majority of the zircons yield ages between 90 and $170 \mathrm{Ma}(\mathrm{n}=11$; Fig. 4i)

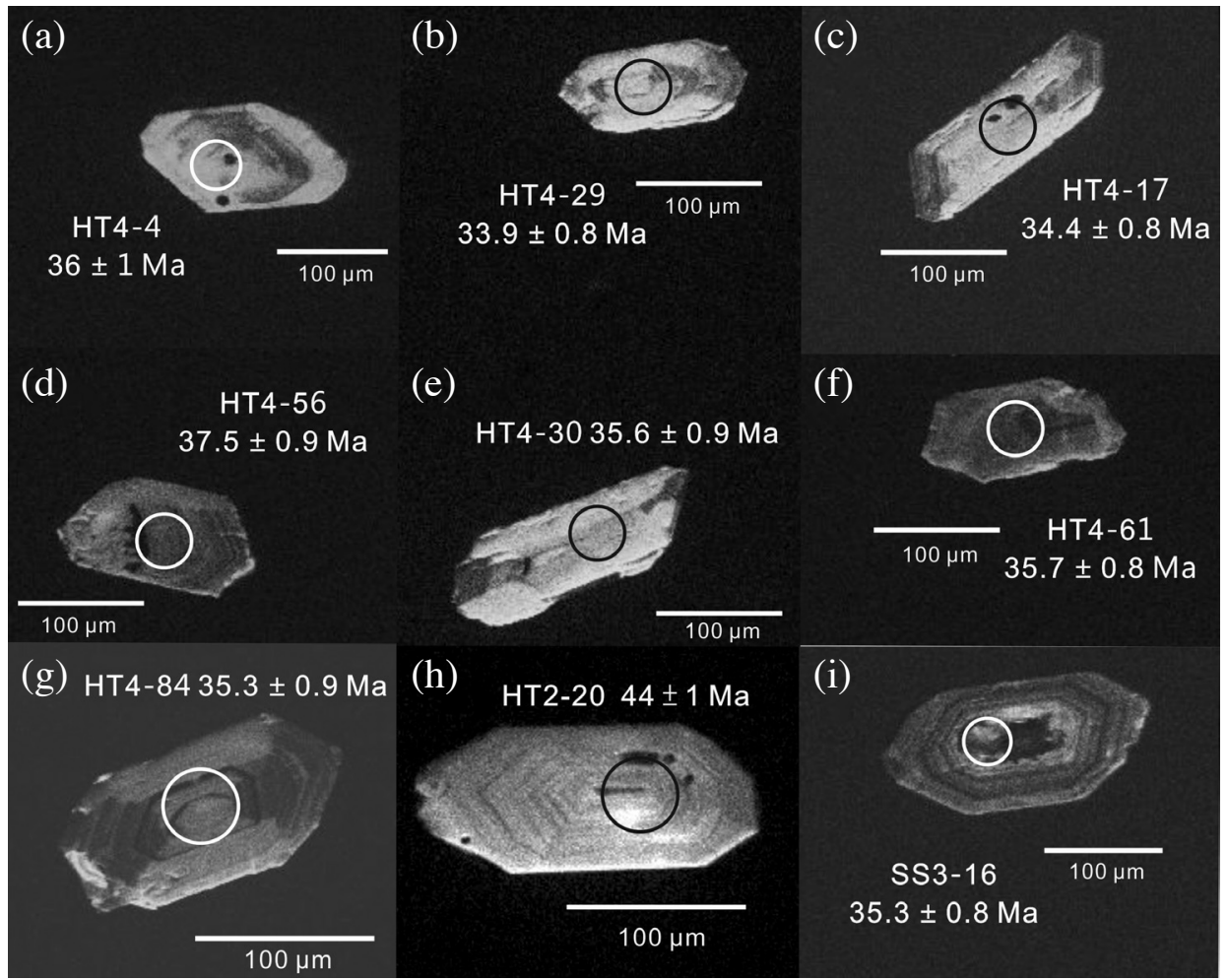

Fig. 3. Cathodoluminescence images of zircons with ages of 33 - 44 Ma from the Hsitsun Formation (a) - (h) and the Szeleng Sandstone (i). Circles indicate the locations of $\sim 25 \mu \mathrm{m}$ laser ablation spots. 


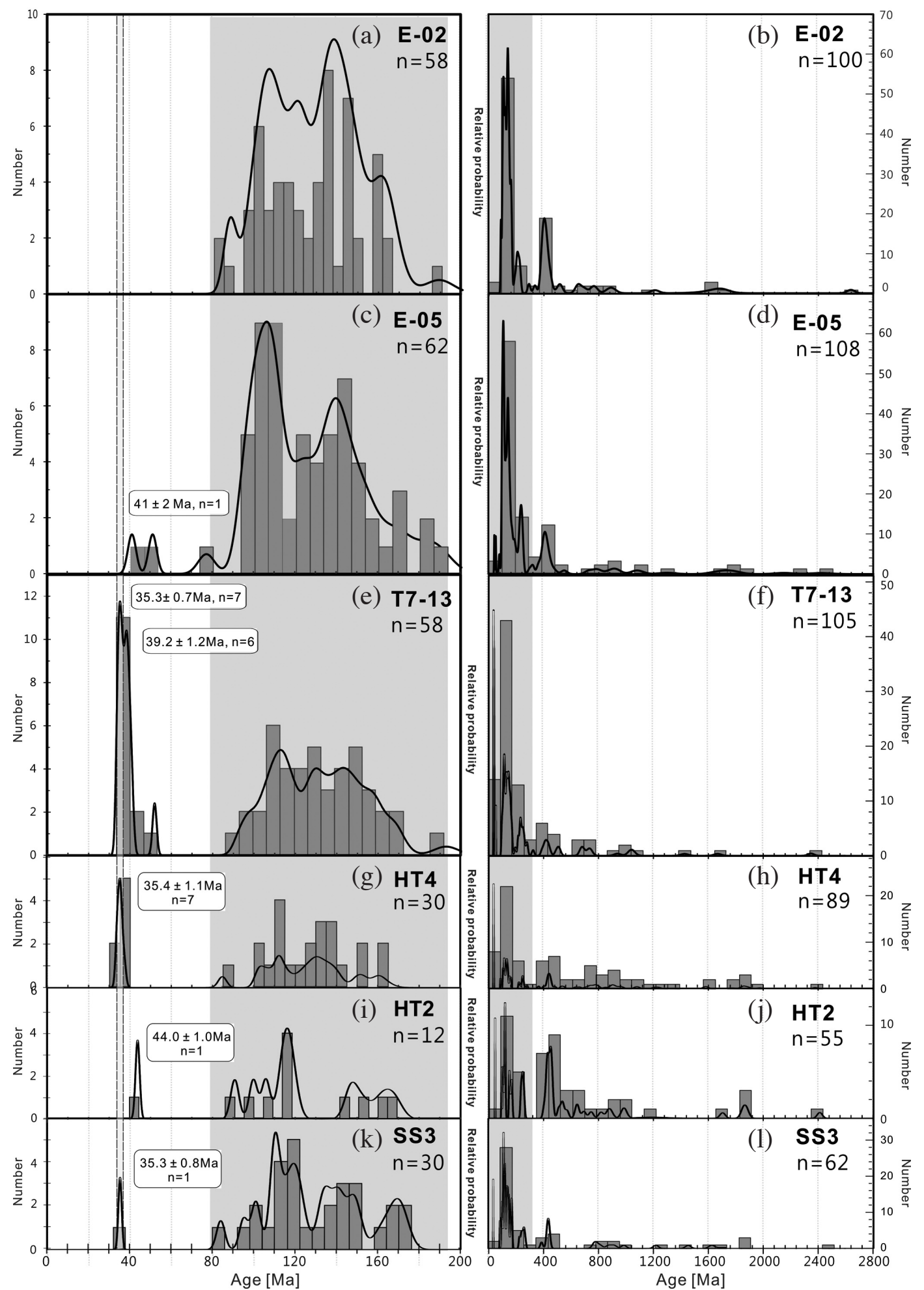

Fig. 4. Probability density curves for detrital zircons from the four samples analyzed during this study, where left columns only shows zircons with agers of $<200 \mathrm{Ma}$ and right columns show all data. 

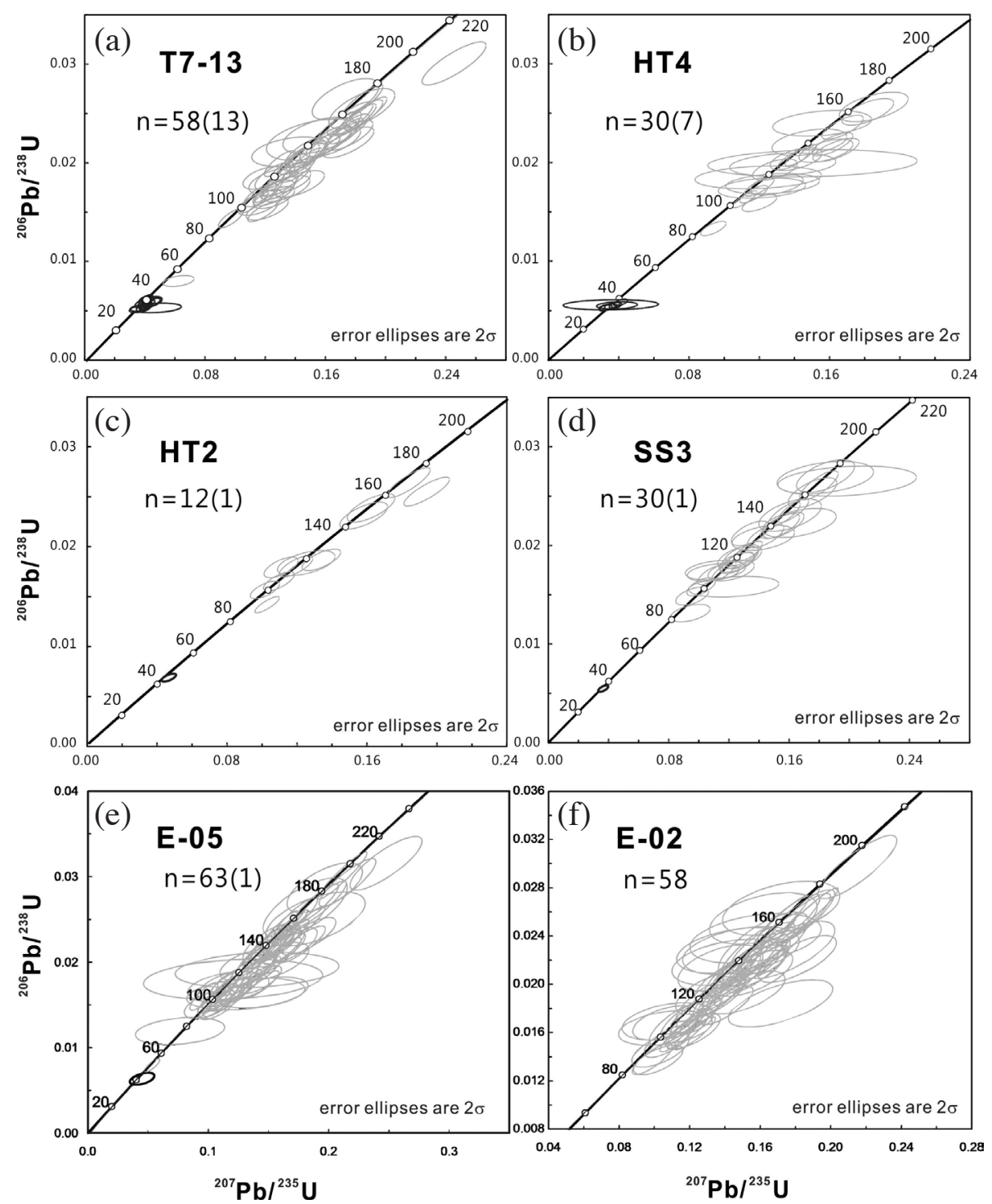

Fig. 5. Concordia diagrams for detrital zircons with ages of $<200 \mathrm{Ma}$, including the mean age of the youngest $\mathrm{n}$ (number in parentheses) number of zircons and the age of the youngest zircon within each sample.

(a)

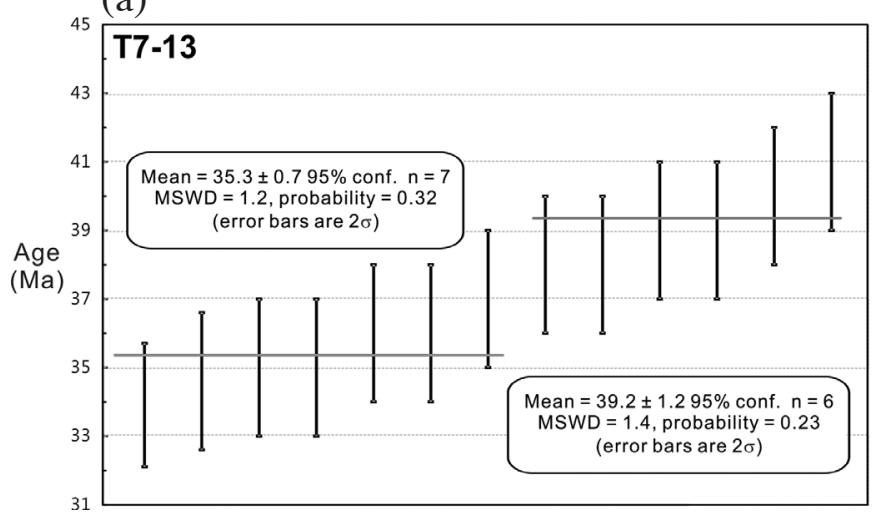

(b)

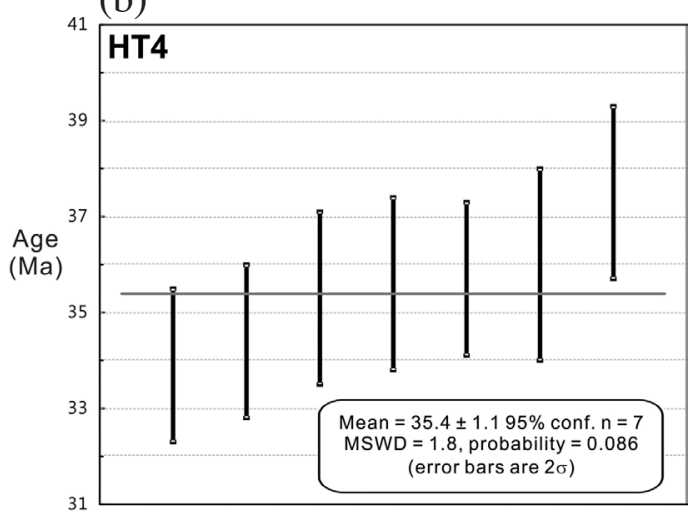

Fig. 6. Distribution of ages of the youngest groups of zircons from samples T7-13 (a) and HT4 (b), including the average age of the youngest $n$ (number in parentheses) zircons and the age of the youngest zircon within each sample. MSWD: mean square weighted deviation. 
with a major cluster at $109 \pm 3 \mathrm{Ma}($ range $91-119 \mathrm{Ma}, \mathrm{n}=7)$ and the rest clustering between 168 and 147 Ma (mean 157 $\pm 3 ; n=4)$. Only one grain from this sample has yielded a Cenozoic age of $44.0 \pm 1.0 \mathrm{Ma}$.

The sample SS3 contains 62 detrital zircons for which the ages range from $35.3 \pm 0.8$ to $2465 \pm 14 \mathrm{Ma}$ (Figs. 4k and 1). 47\% of these zircons have yielded ${ }^{206} \mathrm{~Pb} /{ }^{238} \mathrm{U}$ ages between 172 and $84 \mathrm{Ma}(\mathrm{n}=29$; Fig. 4k), similar to the range of ages from sample T7-13. Only one zircon (SS316) of the 62 analyzed grains has yielded a Cenozoic age (Fig. 4k; Table 1). This zircon is approximately the same age as some of the zircons from Hsitsun Formation samples T7-13 and HT4 (Fig. 4).

\section{DISCUSSION}

Detrital zircon ages are thought to pre-date the deposition of the hosting sedimentary rocks and therefore can only constrain the maximum age of deposition (DeCelles et al. 2007; Dickinson and Gehrels 2009; Tucker et al.
2013). It should be noted, however, that interpretations of the youngest ages that rely on single or a small number of zircons maybe highly uncertain or meaningless. Dickinson and Gehrels (2009), therefore, suggested that the youngestage interpretation be based on multiple grain ages, not the youngest single grain age.

\subsection{Depositional Age of the Hsitsun Formation}

In the samples from Taiwan, two samples, T7-13 and HT-4, yielded more than the minimum number of zircon ages necessary for determining the maximum age of deposition whereas three of the remaining samples, E-05, HT-2, and SS-3, had one or two grains of Cenozoic age. The last sample, E-02, yielded no grains of Cenozoic age. Samples T7-13 and HT-4, from the Hsitsun Formation, yielded youngest zircon ages of $35.9 \pm 1.0$ and $35.4 \pm 1.1$, respectively. In fact, $>10 \%$ (14 of 105 zircons) of the ages obtained for sample T7-13 are younger than $40 \mathrm{Ma}$ and 8\% (7 of 89 zircons) of the zircons from sample HT4 yield ages of

Table 1. U-Pb isotopic data for the youngest groups of zircons within the four samples analyzed in this study.

\begin{tabular}{|c|c|c|c|c|c|c|c|c|c|c|c|}
\hline Spot & $\mathrm{Th} / \mathrm{U}$ & $\mathbf{U}_{\mathrm{ppm}}$ & ${ }^{207} \mathrm{~Pb} /{ }^{206} \mathrm{~Pb}$ & $1 \sigma$ & ${ }^{207} \mathrm{~Pb} /{ }^{235} \mathrm{U}$ & $1 \sigma$ & ${ }^{206} \mathrm{~Pb} /{ }^{238} \mathrm{U}$ & $1 \sigma$ & error corr. & INFERRED AGE (Ma) & $1 \sigma$ \\
\hline \multicolumn{12}{|c|}{ T7-13 E121.45076/N 24.64013 Elev. 1066m } \\
\hline 73 & 0.47 & 911 & 0.04793 & 0.00257 & 0.03480 & 0.00245 & 0.00527 & 0.00014 & 0.37734 & 33.9 & 0.9 \\
\hline 37 & 0.40 & 768 & 0.05329 & 0.00103 & 0.03955 & 0.00159 & 0.00538 & 0.00015 & 0.69352 & 34.6 & 1 \\
\hline 56 & 0.56 & 1016 & 0.04974 & 0.00111 & 0.03744 & 0.00167 & 0.00546 & 0.00016 & 0.65697 & 35 & 1 \\
\hline 64 & 0.85 & 219 & 0.06219 & 0.00744 & 0.04638 & 0.00694 & 0.00541 & 0.00020 & 0.24706 & 35 & 1 \\
\hline 3 & 0.60 & 1144 & 0.05172 & 0.00107 & 0.03968 & 0.00172 & 0.00557 & 0.00017 & 0.70410 & 36 & 1 \\
\hline 96 & 0.51 & 1742 & 0.05145 & 0.00078 & 0.04013 & 0.00138 & 0.00566 & 0.00016 & 0.82204 & 36 & 1 \\
\hline 76 & 0.63 & 1075 & 0.05272 & 0.00083 & 0.04213 & 0.00148 & 0.00580 & 0.00016 & 0.78527 & 37 & 1 \\
\hline 18 & 0.53 & 609 & 0.05302 & 0.00149 & 0.04360 & 0.00232 & 0.00596 & 0.00019 & 0.59911 & 38 & 1 \\
\hline 80 & 0.34 & 498 & 0.04657 & 0.00147 & 0.03783 & 0.00217 & 0.00589 & 0.00019 & 0.56236 & 38 & 1 \\
\hline 19 & 1.49 & 1052 & 0.05447 & 0.00115 & 0.04507 & 0.00200 & 0.00600 & 0.00019 & 0.71361 & 39 & 1 \\
\hline 57 & 1.33 & 792 & 0.05164 & 0.00229 & 0.04266 & 0.00322 & 0.00600 & 0.00023 & 0.50786 & 39 & 1 \\
\hline 103 & 0.37 & 567 & 0.04619 & 0.00146 & 0.03994 & 0.00197 & 0.00627 & 0.00017 & 0.54970 & 40 & 1 \\
\hline 97 & 0.63 & 1087 & 0.04607 & 0.00081 & 0.04048 & 0.00145 & 0.00637 & 0.00017 & 0.74504 & 41 & 1 \\
\hline \multicolumn{12}{|c|}{ HT2 E 121.44867/N 24.64343 Elev. 1094 m } \\
\hline HT2-20 & 1.02 & 780 & 0.04923 & 0.00085 & 0.04670 & 0.00163 & 0.00688 & 0.00016 & 0.66629 & 44 & 1 \\
\hline \multicolumn{12}{|c|}{ SS3 E 121.44429/N 24.64684 Elev. 1094 m } \\
\hline SS3-16 & 2.86 & 1520 & 0.04812 & 0.00084 & 0.03645 & 0.00129 & 0.00549 & 0.00013 & 0.66908 & 35.3 & 0.8 \\
\hline \multicolumn{12}{|c|}{ HT4 E 121.45493/N 24.65403 Elev. 1054 m } \\
\hline HT4-29 & 1.02 & 494 & 0.04467 & 0.00127 & 0.03243 & 0.00153 & 0.00527 & 0.00012 & 0.48264 & 33.9 & 0.8 \\
\hline HT4-17 & 0.40 & 505 & 0.04619 & 0.00216 & 0.03408 & 0.00215 & 0.00535 & 0.00013 & 0.38517 & 34.4 & 0.8 \\
\hline HT4-84 & 0.68 & 409 & 0.04864 & 0.00162 & 0.03683 & 0.00200 & 0.00549 & 0.00014 & 0.46960 & 35.3 & 0.9 \\
\hline HT4-30 & 0.25 & 319 & 0.05112 & 0.00521 & 0.03900 & 0.00476 & 0.00553 & 0.00015 & 0.22224 & 35.6 & 0.9 \\
\hline HT4-61 & 0.75 & 1283 & 0.04904 & 0.00080 & 0.03760 & 0.00123 & 0.00556 & 0.00012 & 0.65976 & 35.7 & 0.8 \\
\hline HT4-4 & 0.95 & 263 & 0.04607 & 0.01314 & 0.03552 & 0.01110 & 0.00559 & 0.00021 & 0.12021 & 36 & 1 \\
\hline HT4-56 & 0.60 & 699 & 0.05105 & 0.00110 & 0.04101 & 0.00166 & 0.00583 & 0.00014 & 0.59325 & 37.5 & 0.9 \\
\hline
\end{tabular}


ca. $35 \mathrm{Ma}$ (Fig. 6b) strongly supporting a maximum depositional age of $\sim 35$ Ma for the exposed Hsitsun Formation.

\subsection{Depositional Age of the Szeleng Sandstone}

Samples SS-3 and E-05, from the Szeleng Sandstone, yield peak ages defined by one and two ages, respectively and, although not meaningful for defining the maximum age of deposition, are consistent with its stratigraphic position above the Hsitsun Formation. The maximum depositional age of the Hsitsun Formation constrains the age of the Szeleng Sandstone to be younger than $35 \mathrm{Ma}$ (Fig. 2). In addition, the youngest age of the Szeleng Sandstone is constrained by the presence of NP23 calcareous nannoplankton near the base of the Paling Formation, which overlies the Szeleng Sandstone in northern Taiwan (Huang 1977, 1979). These age constraints indicate that the Szeleng Sandstone was deposited between 35 and $30 \mathrm{Ma}$ (i.e., between the Late Eocene and Early Oligocene). This interpretation is consistent with the presence of abundant Early Oligocene Shihtsaoan shelf fauna of the foraminiferal Globigerina ampliapertura Zone within the uppermost Szeleng Sandstone in the Peishihchi section (Huang and Cheng 1983). The biostratigraphic age of the G.ampliapertura Zone is P16 - P19 whereas the top of NP23 yields an age of ca. 30 Ma (Fig. 2; Berggren et al. 1995; Berggren and Pearson 2006; Pearson et al. 2006; Wade et al. 2011).

Previous research has identified large Nummulites junbarensis foraminifera within the Szeleng Sandstone (Fong et al. 1994) and Matsumaru (2005) suggested that these foraminifera correlated with Early-Middle Eocene foraminifera in the Akashimisaki Formation (Zone NP14) in Japan. The new data presented in this study, however, suggest that the $N$. junbarensis fossils within the Szeleng Sandstone have been reworked. Shea et al. (2011) reached a similar conclusion for similar fossils in the central Hsuehshan Range.

\subsection{Tectonic Implications for the New Strata Age}

Southern Taiwan and adjacent offshore areas contain a 37 - 30 Ma unconformity associated with uplift and erosion caused by local fault-block rotation that pre-dates the breakup unconformity formed by the opening of the South China Sea (Lin et al. 2003; Huang et al. 2012). Huang et al. (2012) suggested the Szeleng Sandstone was deposited between 47.8 and $39 \mathrm{Ma}$ with a break-up unconformity at 39 - 33 Ma following the deposition of the Szeleng Sandstone (Fig. 2). Our new data indicate that the Hsitsun Formation was deposited at ca. $35 \mathrm{Ma}$ and that the $1200 \mathrm{~m}$ thickness of the Szeleng Sandstone was deposited at 35 - $30 \mathrm{Ma}$, suggesting that this region underwent continuous sedimentation without a depositional gap (Fig. 4). The age spectrums from the Hsitsun Formation and Szeleng Sandstone are also quite similar, suggesting a similar source (Fig. 4). In fact, Eocene rifting stage is associated with many magmatic events that could be the source for the Eocene zircon grains (Chung et al. 1995; Chen et al. 1997; Lin et al. 2003).

Teng (1990) have also suggested that the Lishan fault represents a major normal fault that formed the east boundary of a half-graben basin during the rifting stage. The sediments of the northern Hsuehshan Range are interpreted to have been deposited in the half-graben and, based on the results presented here, preserve continuous deposition. In contrast, the area east of the Lishan fault represents the footwall that may have been uplifted during rifting and may therefore record a breakup unconformity. This interpretation provides important context for future research in northern Taiwan.

Accurate stratigraphic ages in northern Taiwan are also critical to solving problems associated with correlating stratigraphic sequences between the northern to southern Hsuehshan Range. Although paleontological evidence is useful, our study on U-Pb zircon ages shows that the middle Eocene Nummulites are reworked. Because Nummulites have been observed in various places in central to southern Hsuehshan Range, these new findings suggest that the geologic and stratigrahic context of the Nummulites fossils needs to be reexamined throughout Taiwan. This study also puts emphasis on the need to conduct more detrital zircon dating in different areas of Hsuehshan Range to better constrain the correlation of units throughout the Hsuehshan Range and to better understand the rifting history along the continental margin of Eurasia.

\section{CONCLUSIONS}

The youngest detrital zircons in the Hsitsun Formation yield an age cluster at $35.4 \pm 1.1 \mathrm{Ma}$. This sedimentary unit produced a zircon population comprising $>8 \%$ Cenozoic zircons. Combining these data with the biostratigraphic age of the overlying Oligocene Paling Formation suggests that the Szeleng Sandstone was deposited between 35 and $30 \mathrm{Ma}$, indicating the Nummulites junbarensis fossils within this sandstone unit have been reworked. The new data provide evidence of continuous sedimentation between the Paling Formation and the Szeleng Sandstone, indicating that the sedimentary sequences exposed along the Northern CrossIsland Highway Transect do not contain a depositional gap or unconformity.

Acknowledgements We thank P. Q. Lai, H. M. Tu, Y. R. $\mathrm{Wu}$, and Y.C. Chung for their assistance during fieldwork. We also thank Drs. Y. L. Yeh, C. W. Chien, W. S. Chen, C. W. Lin, M. Walia, and M. L. Hsieh for valuable discussions that improved this paper. Comments and suggestions from Prof. T. Byrne and three other anonymous reviewers helped to improve an early version of this manuscript. This project was financially supported by Case B10522 from the Central Geological Survey MOEA, and MOST under grant numbers 104-2116-M-194-013. 


\section{REFERENCES}

Andersen, T., 2002: Correction of common lead in U-Pb analyses that do not report ${ }^{204} \mathrm{~Pb}$. Chem. Geol., 192, 5979, doi: 10.1016/S0009-2541(02)00195-X. [Link]

Berggren, W. A. and P. N. Pearson, 2006: Tropical to subtropical planktonic foraminiferal zonation of the Eocene and Oligocene. Cushman Foundation Special Publication, 41, 29-40.

Berggren, W. A., D. V. Kent, C. C. Swisher, and M.-P. Aubry, 1995: A revised Cenozoic geochronology and chronostratigraphy. In: Berggren, W. A., D. V. Kent, M.-P. Aubry, and J. Hardenbol (Eds.), Geochronology, Time Scales, and Global Stratigraphic Correlation, Society for Sedimentary Geology, Tulsa, Okla, 129-212, doi: 10.7916/D8XD1B1H. [Link]

Chang, L. S., 1962: A biostratigraphic study of the Oligocene in northern Taiwan based on smaller foraminifera. Proc. Geol. Soc. China, 5, 47-64.

Chang, L. S., 1973: A biostratigraphic study of the so-called Slate Formation in Taiwan based on smaller foraminifera: III. Sankuang-Hsiuluan area along the upper courses of the Tanshiuho and the Yulochi. Proc. Geol. Soc. China, 16, 69-84.

Chang, L. S., 1975: Biostratigraphy of Taiwan Contributions to the Geology and Palaeontology of Southeast Asia, CL VIII. Geology and Palaeontology of Southeast Asia, 15, 337-361.

Chen, C. H., C. Y. Lee, T. C. Huang, and J. S. Ting, 1997: Radiometric ages and petrological and geochemical aspects of some late Cretaceous and Paleogene volcanic rocks beneath the northern offshore of Taiwan. Petrol. Geol. Taiwan, 31, 61-88.

Chen, C. H., 2000: Geologic map of Taiwan. Central Geological Survey, MOEA, ROC.

Chen, W. S., 2016: Introduction of Geology in Taiwan, Geol. Soc. of Taiwan, 204 pp.

Chiu, H. Y., S. L. Chung, F. Y. Wu, D. Liu, Y. H. Liang, I. J. Lin, Y. Iizuka, L. W. Xie, Y. Wang, and M. F. $\mathrm{Chu}, 2009$ : Zircon U-Pb and $\mathrm{Hf}$ isotopic constraints from eastern Transhimalayan batholiths on the precollisional magmatic and tectonic evolution in southern Tibet. Tectonophysics, 477, 3-19, doi: 10.1016/j.tecto.2009.02.034. [Link]

Chung, S.L., T.Frank Yang, C.y.Lee, and C.H.Chen, 1995: The igneous provinciality in Taiwan: Consequence of continental rifting superimposed by Luzon and Ryukyu subduction systems. J. Southeast Asian Earth Sci., 11, 73-80, doi: 10.1016/0743-9547(94)00040-L. [Link]

DeCelles, P. G., B. Carrapa, and G. E. Gehrels, 2007: Detrital zircon $\mathrm{U}-\mathrm{Pb}$ ages provide provenance and chronostratigraphic information from Eocene synorogenic deposits in northwestern Argentina. Geology, 35, 323, doi: 10.1130/G23322A.1. [Link]
Dickinson, W. R. and G. E. Gehrels, 2009: Use of U-Pb ages of detrital zircons to infer maximum depositional ages of strata: A test against a Colorado Plateau Mesozoic database. Earth Planet. Sci. Lett., 288, 115-125, doi: 10.1016/j.eps1.2009.09.013. [Link]

Fong, C. C. K., T. Huang, and K. Shea, 1994: New occurrence of larger Foraminifera in northern Taiwan and its stratigraphic significance. Spec. Publ. Cent. Geol. Surv., 8, 205-212.

Harley, S. L., N. M. Kelly, and A. Moller, 2007: Zircon Behaviour and the Thermal Histories of Mountain Chains. Elements, 3, 25-30, doi: 10.2113/gselements.3.1.25. [Link]

Ho, C. S., 1986: A synthesis of the geologic evolution of Taiwan. Tectonophysics, 125, 1-16, doi: 10.1016/00401951(86)90004-1. [Link]

Huang, C. Y. and Y. M. Cheng, 1983: Oligocene and Miocene planktic foraminiferal biostratigraphy of northern Taiwan. Proc. Geol. Soc. China, 26, 21-56.

Huang, C. Y., Y. Yen, Q. Zhao, and C. T. Lin, 2012: Cenozoic stratigraphy of Taiwan: Window into rifting, stratigraphy and paleoceanography of South China Sea. Chin. Sci. Bull., 57, 3130-3149, doi: 10.1007/s11434012-5349-y. [Link]

Huang, T. C., 1977: Calcareous nannoplankton stratigraphy of the Upper Wulai Group (Oligocene) in northern Taiwan. Petrol. Geol. Taiwan, 14, 147-179.

Huang, T. C., 1979: The Oligocene/Miocene boundary in Taiwan. Mem. Geol. Soc. China, 3, 103-123.

Huang, T. C., 2007: The Nummulites in Szeleng Sandstone from the Chinmienshan area, northeastern Hsuehshan Range and its significance of sandstone. Taiwan Mining Industry, 59, 18-36.

Jackson, S. E., N. J. Pearson, W. L. Griffin, and E. A. Belousova, 2004: The application of laser ablation-inductively coupled plasma-mass spectrometry to in situ U-Pb zircon geochronology. Chem. Geol., 211, 47-69, doi: 10.1016/j.chemgeo.2004.06.017. [Link]

Knittel, U., S. Suzuki, N. Nishizaka, K. Kimura, W.-L. Tsai, H.-Y. Lu, Y. Ishikawa, Y. Ohno, M. Yanagida, and Y.-H. Lee, 2014: U-Pb ages of detrital zircons from the Sanbagawa Belt in western Shikoku: Additional evidence for the prevalence of Late Cretaceous protoliths of the Sanbagawa Metamorphics. J. Asian Earth Sci., 96, 148-161, doi: 10.1016/j.jseaes.2014.09.001. [Link]

Košler, J., H. Fonneland, P. Sylvester, M. Tubrett, and R.B. Pedersen, 2002: U-Pb dating of detrital zircons for sediment provenance studies - a comparison of laser ablation ICPMS and SIMS techniques. Chem. Geol., 182, 605-618, doi: 10.1016/s0009-2541(01)00341-2. [Link]

Lee, Y. H., T. Byrne, W. H. Wang, W. Lo, R. J. Rau, and H. Y. Lu, 2015: Simultaneous mountain building in 
the Taiwan orogenic belt. Geology, 43, 451-454, doi: 10.1130/G36373.1. [Link]

Lin, A. T., A. B. Watts, and S. P. Hesselbo, 2003: Cenozoic stratigraphy and subsidence history of the South China Sea margin in the Taiwan region. Basin Res., 15, 453478, doi: 10.1046/j.1365-2117.2003.00215.x. [Link]

Ludwig, K. R., 2003: User's Manual for Isoplot 3.00: A Geochronological Toolkit for Microsoft Excel, Berkeley CA.

Matsumaru, K., 2005: Nummulites junbarensis and Assilina formosensis (Late Early to early Middle Eocene) from Taiwan (Formosa). Revue de Palébiologie, 24, 551-561.

Morton, A. C., J. C. Claoué-Long, and C. Berge, 1996: SHRIMP constraints on sediment provenance and transport history in the Mesozoic Statfjord Formation, North Sea. J. Geol. Soc., 153, 915-929, doi: 10.1144/ gsjgs.153.6.0915. [Link]

Ooe, Z., 1931: Explanatory Text of the Geological Map of Taiwan: Ritozan Sheet No. 18, Bureau of Productive Industries, Government-General of Formosa.

Pearson, P. N., R. K. Olsson, B. T. Huber, C. Hemleben, and W. A. Berggren, 2006: Atlas of Eocene Planktonic Foraminifera, Cushman Foundation, 514 pp.

Shea, K. S., 2009: Discussion of biostratigraphic correlation in the Hsuehshan Range. Spec. Publ. Cent. Geol.Surv., 22, 13-45.

Shea, K. S., C. S. Horng, M. M. Chen, and N. T. Yu, 2011: Fossil study of the Chiayang Formation, the middle member of the Meichi Sandstone and the base of the Lushan Formation in central Taiwan: age constraints on the formations on the eastern flank of the Southern
Hsuehshan Range. Spec. Publ. Cent. Geol. Surv., 25, 133-166.

Sláma, J., J. Košler, D. J. Condon, J. L. Crowley, A. Gerdes, J. M. Hanchar, M. S. A. Horstwood, G. A. Morris, L. Nasdala, N. Norberg, U. Schaltegger, B. Schoene, M. N. Tubrett, and M. J. Whitehouse, 2008: Plešovice zircon - A new natural reference material for $\mathrm{U}-\mathrm{Pb}$ and Hf isotopic microanalysis. Chem. Geol., 249, 1-35, doi: 10.1016/j.chemgeo.2007.11.005. [Link]

Teng, L. S., 1990: Geotectonic evolution of late Cenozoic arc-continent collision in Taiwan. Tectonophysics, 183, 57-76, doi: 10.1016/0040-1951(90)90188-e. [Link]

Teng, L. S., Y. Wang, C. H. Tang, C. Y. Huang, T. C. Huang, M. S. Yu, and A. Ke, 1991: Tectonic Aspects of the Paleogene Depositional Basin of Northern Taiwan. Proc. Geol. Soc. China, 34, 313-335.

Tucker, R. T., E. M. Roberts, Y. Hu, A. I. Kemp, and S. W. Salisbury, 2013: Detrital zircon age constraints for the Winton Formation, Queensland: Contextualizing Australia's Late Cretaceous dinosaur faunas. Gondwana Res., 24, 767-779, doi: 10.1016/j.gr.2012.12.009. [Link]

Wade, B. S., P. N. Pearson, W. A. Berggren, and H. Pälike, 2011: Review and revision of Cenozoic tropical planktonic foraminiferal biostratigraphy and calibration to the geomagnetic polarity and astronomical time scale. Earth-Sci. Rev., 104, 111-142, doi: 10.1016/j. earscirev.2010.09.003. [Link]

Yu, N. T., L. S. Teng, W. S. Chen, L. F. Yue, and M. M. Chen, 2013: Early post-rift sequence stratigraphy of a Mid-Tertiary rift basin in Taiwan: Insights into a siliciclastic fill-up wedge. Sediment. Geol., 286-287, 39-57, doi: 10.1016/j.sedgeo.2012.12.009. [Link] 